\title{
SOME CHARACTERISTICS OF ARTICLES PUBLISHED IN THE NIGERLAN JOURNAL OF ANIMAL PRODUCTION
}

\author{
S. ADEWOLE \\ Natiơnal Animal Production Research Institute, \\ Ahmadu Bello University, Shika - Zaria \\ (Received 31 October, 1990, accepted 20 February, (1/91)
}

\begin{abstract}
Using the articles published in the volume 10-14 (1983-1987) of the Nigerian Journal of Animal Production (NJAP), articles profiles and authors' livestock training background were determined. Eighty-one (81) out of 226 were singlt authored and the balance authored by two or more people. Twelve (12) authors represents the 'core authors' of the journal. This figure appears rather low, from a total of 226 authors. Poultry production is the most authored fieid in animal production studies; while Nsukka, Zaria, Ibadan and Vom produced the highest number of animal scientists that authored the articles in the volumes 10-14 of NJAP. This group accounts for more than $74 \%$ of the institutional affiliation of authors to the journal.
\end{abstract}

\section{INTRODUCTION}

Information on the characteristics of the literature of any subject field is a useful bibliographic tool for both librarians and researchers (Martyn, 1975). The significance of the study of the characteristics of works contained in a publication lies in the fact that it contributes to the understanding of, and insight into that subject.

Okanlawon (1984) on characteristics of veterinary medicine literature observed that an understanding of certain basic characteristics of the literature of the subject has many important contributions to make to the improvement of acquisition and biblographical control of that literature. The need for bibliographic control through proper examination, documentation and organisation, and the retrieval of literature in a group field like animal production in Nigeria cannot be over-emphasized. Saracevic and Pcrk $(19 / 3)$ sees literature analysis as fundamental to all other analyses.

Nigeria Journal of Animal Production 18 (1991)
It is difficult to determine all the characteristics of a subject field, because they are too numerous, and they do not lend themselves easily to assessment. However, the most commonly user methods: Citation analysis, abstract analysis, and the analysis of a compiled bibliograph still have their inherent shortcomings. For instance, the first method of analysis is not comprehensive enough, as not all that is published or read ever gets cited; the second method has its bias towards journals and periodicals, meaning that materials published outside these medium never get abstracted in an abstract analysis.

Applying some of these accepted methods of literature analyses to the Nigerian Joumal of Animal Production (NJAP), the following objectives have been chosen for analyses:-

1. Identify the authors contributing to the Joumal.

2. Reveal the strength of such authors through a ranked list of an author productivity

3. Determine the "Core-Author to the journal.

4. Examine the status of article published in terms of being joint or multiple

5. Examine the specie scatter of the articles. The basic limitation of the study in this direction is that only five volumes (i.c Vol. 10-14; 1983-87) of the Joumal. were analysed.

\section{MATERIALS AND METHODS}

The sources of data for this study were the articles published by the Nigerian Journal of Animal Production (NJAP) during the years 1983 - 1987; i.e Volumes 10)-14. The choice of time span was diclated by convenicnce. Puhlish. ing of the Jonmal started in 1974, but publicat tion was not as regular as it should be. 
TABLE 1. DISPERSION OF ARTICLES AMONG SPECIES IN VOL. 10-14 AND STATUS OF ARTICLES.

\begin{tabular}{|c|c|c|c|}
\hline \multirow{2}{*}{ Species } & \multirow[b]{2}{*}{$\begin{array}{l}\text { Article } \\
\text { No.. }\end{array}$} & \multicolumn{2}{|c|}{ Status } \\
\hline & & Single & Joint \\
\hline$\overline{\text { Poultry Production }}$ & 79 & 31 & 48 \\
\hline Cattle Production & 37 & 11 & 26 \\
\hline $\begin{array}{l}\text { Swinc Breeding } \\
\text { and reproduction }\end{array}$ & 28 & 11 & 17 \\
\hline $\begin{array}{l}\text { Small Rumitıants } \\
\text { research }\end{array}$ & 28 & 11 & 17 \\
\hline $\begin{array}{l}\text { Feed, Forage develop" } \\
\text { ment and crop residue }\end{array}$ & 17 & 3 & 14 \\
\hline General livestock studies & 17 & 6 & 11 \\
\hline Dairy Research & 11 & 4 & 7 \\
\hline Rabbitry Research & 7 & 2 & 5 \\
\hline Snail Breeding & 2 & 2 & - \\
\hline Total & 226 & 81 & 145 \\
\hline
\end{tabular}

Publication from 1983-1987 were however regular.

For every article published in each issue, an index card was made. Such information as below were noted on the card:

(i) The name(s) of the author(s)

(ii) The address of the authur(s)

(iii) Title of article including date

(iv) Species treatment of article.

Attempt is made at identifying each author so as to enable his professional background in the industry to be determined. Hence, authors with B.Sc, M.Sc, etc prefix were noted from their veterinary colleagues.

For all cases of joint authorship, the address of the first author determines the address for the article. For articles in which the authors are addressed locally and foreign, the Nigerian address was recorded. All institutions attached to Universities were recorded under the Univer- sity. For the purpose of the present study, presidential, opening and Governor's addresses were ignored.

\section{RESULTS AND DISCUSSION}

Two hundred and twenty-six (226) articles were published in the 5 volumes used for this study. 81 of these articles were single authored while the remaining 145 were joint authored articles. This discovery tallies with earlier works carried out by Price in 1963 and Clerke in 1964 . They agreed that modern scientific paper trend is towards multiple authorship than individual. Price (1963) concludes that the trend towards multiple authorship is a phenomenon which has been increasing steadily and ever more rapidly since the begining of this century.

Further exposition on the articles show that they can be classified under the following subject treatises: poultry production, swine or piggery, small ruminants, cattıe, snail and rabittery. Others are forage development and crop residue, dairy development, animal reproduction, and others that are of general nature. The number of article dispersion per class is as shown in Table 1. There were very few publications on snail and rabbits research in the journal as there are 2 and 7 articles respectively.

Table 2 shows the institutional affiliations of the authors of the articles. The picture one sees from this table is that the older livestock training institutions; Viz:- Ahmadu Bello University, Zaria; University of Nigeria, Nsukka; University of Ibadan; and the Nigerian Veterinary Research Institute, Vom account for 175 of the total published articles. This is more than $74 \%$ of the total articles used for the studies.

A survey of the authors show that from 226 authors, 61 are veterinarians by training, while the remaining 165 are animal scientists and technologists. This author is able to know this far by his personal knowledge of the authors and a cross-check from peers of the authors.

Table 3 shows the core authors to be I.F.Adu, with 9 articles A.B. Udedibe, with 8 scores; and B. I. Orji with 6 scores. Nine other authors had 5 scores each. 


\section{TABLE 2. INSTITUTIONAL AFFLIATION OF AUTHORS}

Institution No, of

Authors

1. University of Nigeria, Nsukka 54

2. Ahmadu Bello University 51

3. University of Ibadan 37

4. Veterinary Research Institute, Vom 33

Federal University of Technology,

5. Owerri

6. Scattered addresses in the U.S.A. 9

7. University of Maiduguri

8

8. Rivers State University of Technology (Incl. Uniport)

9. Kainji Lake Research Institute, New Bussa

10. Obafemi Awolowo University, IleIfe.

11. Scattered addresses in Australia

12. University of Ilorin

13. Federal University of Technology, Makurdi

3

14. Bendel State University, Ekpoma. 2.

15. Federal University of Technology, Yola

16. Federal University of Technology, Akure

17. Nigerian Institute of Trypanosomiasis Research, Kaduna

18. United Kingdom (U.K)

An identification of the "core authors" within any given discipline provides a good tool for acquisition. Libraries will tend to limit their selection based on articles authored by such "core authors" as this is a ready tool to librarians for aquisition during cuts in book budget. "Core authors" also enable researchers gain access to the appropriate information in their disorganised state. Finding the "core authors" from Table 3 posed the question of which formula to employ. Breadford was interested in finding out the most useful journals for a field as far back as 1948; and thus arranged the journals into a list with the most productive numerically at the top followed by the next most productive and so on. He reasoned that at the end of the day, those at the top would form a nucleus of most uscful sour-

ces for that subject field. This top nucleus was later referred to as the "Core Journal". The emerging table was later transformed into a graph which has won the hearts of bibliometricians. This graphic formulation of the Bradford's law is more consistent with practical situation. Andrew Pope (1975) in accepting the superiority of this graphical analysis to other methods writes "realising the fact that not all bibliographies are complete, potentials for application should be considered and these criteria if applied will make graphical analysis supexior. Toye (1976) and Aiyepeku (1973) applied the core principle to the study of core authors in Entomology and Geography respectively. This paper will do the same with Animal Science. Fig I. shows that the first twelve authors with 5 to 9 articles constitute the 'core authors' of the Nigerian Ioumal of Animal Production. These authors are I. F. Adu, A. B.I. Udedibie, B. I. Orji, K. L. Ayorinde, B. L. A. Fetuga, J. A. Ibeawuchi, S. A. Ikurior, A. U. Kalu, F. C. Obioha, G. C. Okeke, B. N. Okwuosa; and E. Nwokolo. These twelve authors produced 68 articles representing $30.68 \%$ of the total articles.

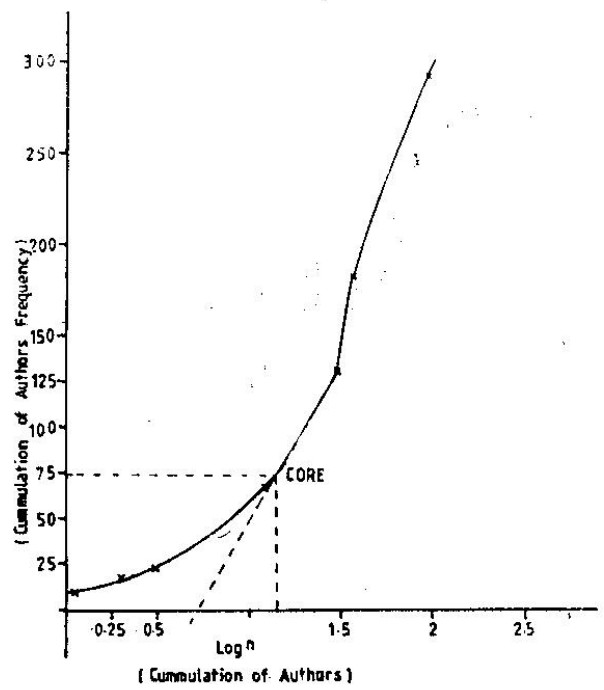

Fig, 1. Bradford hibliogeraphy for corc atuthors 
TABLE 3. RANKED LIST OF AUTHOR PRODUCTIVITY IN THE NIGERIAN JOURNAL OF ANIMAL PRODUCTION VOL. 10-14

\begin{tabular}{|c|c|c|c|}
\hline Author & Productivity & Author & Productivity \\
\hline 1. I. F. Adu & 9 & 45. D. V.Uza & 3 \\
\hline 2. A.B.I. Udedibie & 8 & 46. I. A. Abdulkadir & 2 \\
\hline 3. B. I. Orji & 6 & 47. I. O. Adeleye & 2 \\
\hline 4. K. L. Ayorinde & 5 & 48. J. O. Akinola & 2 \\
\hline 5. 3.L.A. Fetuga & 5 & 49. A. O Akinsoyinu & 2 \\
\hline 6. J. A. Ibeawuchi & 5 & 50. M. Akpapunam & 2 \\
\hline 7. S. A. Ikurior & 5 & 51. O. Alaku & 2 \\
\hline 8. A. U. Kalu & 5 & 52. B. O. Asuquo & 2 \\
\hline 9. F. C. Obioha & 5 & 53. S. T. O. Atta & 2 \\
\hline 10. G. C. Okeke & 5 & 54. G. O. Azubuike & 2 \\
\hline 11. B. N. Okwuosa & 5 & 55. A. K. Chatterjee & 2 \\
\hline 12. E. Nwokolo & 5 & 56. C. N. Chineme & 2 \\
\hline 13. A. M. Agbakoba & 4 & 57. K. Dobel & 2 \\
\hline 14. S. S. Ahmed & 4 & 58. L. O. Eduvie & 2 \\
\hline 15. F. O. I. Anugwa & 4 & 59. O. W. Ehoche & 2 \\
\hline 16. J.S. O. Ayeni & 4 & 60. C. A. Enunwaonye & 2 \\
\hline 17. O. W. Ehoche & 4 & 61. B.C. Eżike & 2 \\
\hline 18. L.S.O. Ene & 4 & 62. T. A. Gbodi & 2 \\
\hline 19. T. N. Kamalu & 4 & 63. E. s. Haruna & 2 \\
\hline 20. C. A. M. Lakpini & 4 & 64. G. Igoeli & 2 \\
\hline 21. M. C. Njike & 4 & 65. M. U. Iloeje & 2 \\
\hline 22. C. C. Nwosu & 4 & 66. J. O. Jegede & 2 \\
\hline 23. S. A. Offiong & 4 & 67. U.S. Krishnamurthy & 2 \\
\hline 24. N. A. Okaeme & 4 & 68. A. S. Kwatu & 2 \\
\hline 25 H. E. Okereke & 4 & 69. S. Legel & 2 \\
\hline 26. J. M. Olomu & 4 & 70. E. A. Lufadeju & 2 \\
\hline 27. E. B. Sonaiya & 4 & 71. K. A. Majiyagbe & 2 \\
\hline 28. T.S. B. Tegbe & 4 & 72. A. U. Mba & 2 \\
\hline 29. E. A. Adebowale & 3 & 73. L. A. Murray & 2 \\
\hline 30. T. A. Adegbola & 3 & 74. A. Naibe & 2 \\
\hline 31. J. A. Adeneye & 3 & 75. D. R. Nawathe & 2 \\
\hline 32. A. M. Balogun & 3 & 76. L. O. Ngere & 2 \\
\hline 33. V. Buvanendran & 3 & 77. D. O. Nnanyelugo & 2 \\
\hline 34. M. Czerski & 3 & 78. A. N. Nnodim & 2 \\
\hline 35. U. J. Ikhatua & 3 & 79. B. O. Nwegbu & 2 \\
\hline 36. O. A. Ikwegbu & 3 & 80. C. I. Nwosuh & 2 \\
\hline 37. T. N. Kámala & 3 & 81. F. C. Obioha & 2 \\
\hline 38. G. W. Kulasek & 3 & 82. S. I. Obaegbulem & 2 \\
\hline 39. F. N. Madubuike & 3 & 83. O. O. Ogunsiji & 2 \\
\hline 40. M. C. Njike & 3 & 84. O. O. Okoli & 2 \\
\hline 41. P. C. Njoku & 3 & 85. S. Okon & 2 \\
\hline 42. A. U. Okoric & 3 & 86. L. A. Uladosu & 2 \\
\hline 43. A. D. Ologhobo & 3 & 87. O. Onwubiko & 2 \\
\hline 44. S. A. S. Olorunju & 3 & 88. A. Onwubuya & 2 \\
\hline
\end{tabular}


TABLE 3 CONT'D

Author Productivity

89. O. A. Osinowo

90. T. Ogunjimi

91. E. O. Oyedipe

92. D. Patric

93. D. I. Sarror

94. A. A. Sekoni

95. B. O. Shodipo

96. I. A. Ukweni

97. J. E. Umoh

98. N. N. Umunna

99. G. E. S. Williams

100. S. N. Abana

101. A. M. Adamu

102. O. A. Adebambo

103. V. O. Adebambo

104. J. O. A. Adeleye

105. Y. M. Adesipe

106. A. A. Adesiyun

107. A. A. Adewuyi

108. S. A. Adeyanju

109. A. A. Adeleye

110. A. O. Adogwa

111. E. C. Agishi

112. F, N. Agamoh

113. W. E. Agu

114. J. A. Agunbiade

115. M. E. Akenova

116. M. Akande

117. K. E. Akinuli

118. O. Akinokun

119. A. A. Akinyemi

120. I. A. Akpan

121. F. Alafiatayo

122. V: A. Aletor

123. W. S. Alhassan

124. P. O. Anagor

125. V. O. Anosa

126. B. M. Anene

127. L. A. O. Asye

128. A. A. Awah

129. M. O. Awogbade

130. P. O. Azike

131. Z. T. Bajeh

132. E. A. Balogun

133. A. O. Bello

134. S. I. Bello
Author

Productivity

135. T. A. Bamiduro

136. K. Benyi

137. J. G. Buchanan-Smith

138. S. N. Carew

139. L. E. Chase

140. H R. Chheda

141. C. R. Chuta

142. P. N. Chidebe

143. Y. Chiejina

144. G. A. O. Chuke

145. I. Dafwang

146. K. B. David-West

147. B. H. Davies

148. P. M. Dawuda

149. P. N. de-Leeuw

150. N. Dim

151. H. U. Edegere

152. H. L. Enos

153. E. E. Erojikwe

154. K. A. N. Esievo

155. B. O. Esonu

156. A. O. Ezeh

157. C. D. Ezeokoli

158. N. E. Ezekiel

159. K. Fuleye

160. I. J. Fulani

161. S. A. Garba

162. A. O. Gbankoto

163. A. Ghaji

164. F. Goween

165. U. Henry

166. J. K. M. Hodasi

167. J. O. Igene

168. M. M. Ikeme

169. A. A. Hemobade

170. A. O. Idufueko

171. A. G. Jagun

172. A. O. Johnson

173. R. A. Joshua

174. S. A. Kayit

175. O. O. Komolafe

176. M. Kownacki

177. R. Krzemnski

178. J. Kumi-Diaka

179. G. W. Kulasck

180. O. Kumuyi

1

1

1

1

1

1

1

1

1

1

1

1

1

1 
TABLE 3 CONT'D

Author Productivity

Author

Productivity

181. G. G. Kwanashie

1×2. O. A. Leigh

183. O. Longe

184. E. C. Luswetti

185. F. N. Madubuike

186. S. A. Manigni

187. J. McGaugh

188. I. Mecha

189. A. Monsi

190. W. E. Moore

191. L. I. Ndife

192. D. A. Ngoka

193. A. Nlube

194. L. N. Nwakalor

195. E. A. Obot

196. V. M. Ofoube

197. E. A. Ogbona

198. G. A. Ogbonnah

199. O. Chajanuka

200. O. O. Ojo

201. J. O. A. Okase

202. M. U. Okeagu

203. A. I. Okeke

1
1
1
1
1
1
1
1
1
1
1
1
1
1
1
1
1
1
1
1
1
1
1

\begin{tabular}{ll}
\hline 204. C. Okere & 1 \\
205. P. N. Okah & 1 \\
206. M. I. Okolo & 1 \\
207. A. O. Okunyiba & 1 \\
208. E. A. Olalokun & 1 \\
209. M. B. Olayiwole & 1 \\
210. B. A. Olufemi & 1 \\
211. O. Olumide & 1 \\
212. J. O. Omamegbe & 1 \\
213. O. O. Oni & 1 \\
214. O. S. Onifade & 1 \\
215. F. O. Oluajo (U. I.) & 1 \\
216. G. I. Onuora & 1 \\
217. B.A. Opasina & 1 \\
218. S. O. Orgu & 1 \\
219. B. I. Orji & 1 \\
220. M. O. Oyatogun & 1 \\
221. N. Pathiraja & 1 \\
222. J. Piotrowski & 1 \\
223. J. T. Raid & 1 \\
224. A. H. Sykes & 1 \\
225. W. P. Taylor & 1 \\
226. c. O. Ubosi & 1 \\
\end{tabular}

TABLE 4. TABLE OF DISTRIBUTION OF AUTHORSHIP IN THE VOL. 10-14

\begin{tabular}{ccccc}
\hline $\begin{array}{c}\text { Frequency } \\
\text { Productivity of } \\
\text { authors }\end{array}$ & No of Authors & $\begin{array}{c}\text { Cumulation of } \\
\text { authors }\end{array}$ & $\begin{array}{c}\text { Cumulation } \\
\text { frequency } \\
\text { of authors }\end{array}$ & Log of Authors \\
\hline 9 & 1 & 1 & 9 & 0.006 \\
8 & 1 & 2 & 17 & 0.301 \\
6 & 1 & 3 & 23 & 0.477 \\
5 & 9 & 12 & 68 & 1.079 \\
4 & 16 & 28 & 132 & 1.447 \\
3 & 17 & 45 & 183 & 1.653 \\
2 & 54 & 99 & 291 & 1.959 \\
1 & 127 & 226 & 418 & 2.302 \\
\hline
\end{tabular}




\section{CONCLUSION}

The evidence generated permits some cautious general conclusion on the reliability of characteristic studies to library services. The use of periodicals in animal science, like in any other scientific discipline, is paramount to research and development. This is why the interest in periodical-based materials has continued to grow as a result of an increase in the intensity of research in this area.

The author ranking produced in Table 3 makes it possible for new scientists in the field of animal production to identify pioneers in the industry, and thereafter search for the works of such authors. Librarians could also use such list as their reference base in literature disposition.

The Nigerian Joumal of Animal Production has come of age. The abstracts, often not more than one or two paragraphs are sufficiently informative. The articles published also reflect the comprehensiveness of the subject matter. The journal would however boost it openness by publishing materials on bibliometrics.

Very litle is published on snail and rabbitery research, and the journal should endeavour to solicit for articles in these areas through its publishers, the Nigerian society for animal production.

The age of cited reference by the authors in their articles reveal an acute dearth of current books and journals in our libraries. Author's references were mostly from publications of the sixties, and at best early seventies. The implication of this to science and technology in a developing industry as animal production cannot be overlooked. Libarians must therefore lool for other means of acquisition outside direct purchase.

\section{REFERENCES}

AIYEPEKU, W.U. 1973. The language and format of geographical literature: a comparative study. Int. Library Review, 5:53-60.

BRADFORD, S. C. 1948. Documentation. London: Crosby Lockwood and Son Ltd., 1948.

CLARKE, C.V. 1976. Obsolenscence of patent literature. J. of Documentation. 32:(1): 3252.

MARTYN, J. Progress in documentation: Citation analysis. $J$. of Documentation 31(2): 1975.

OKANLAWON, O. 1984. Characteristics and bibliographic control of the literature of Veterinary Medicine in Nigeria. M.L.S thesis, A.B.U., Zaria.

POPE, A. 1975. BRADFORD's law and the periodical literature of information science. J. American Soc. Inf. Science, 20(4).

PRINCE, D. J. des. 1963. Little science, big science. Columbia Univ. Press, New York.

SARACEVIC, T. and PERK, L. 1973. Asccrtainingactivitics in a subject arca through bibliometric analysis: Application Io library literature. J. American Soc. IIIf. Science, March-April.

TOYE, 0. 1976. Some characteristics of the Nigerian cntomological literature. Nigeriun J. Entomology, 3: 1976. 